ppi $201502 Z U 4645$

Esta publicación cientifica en formato digital es continuidad de la revista impresa ISSN-Versión Impresa 0798-1406 / ISSN-Versión on line 2542-3185Depósito legal pp

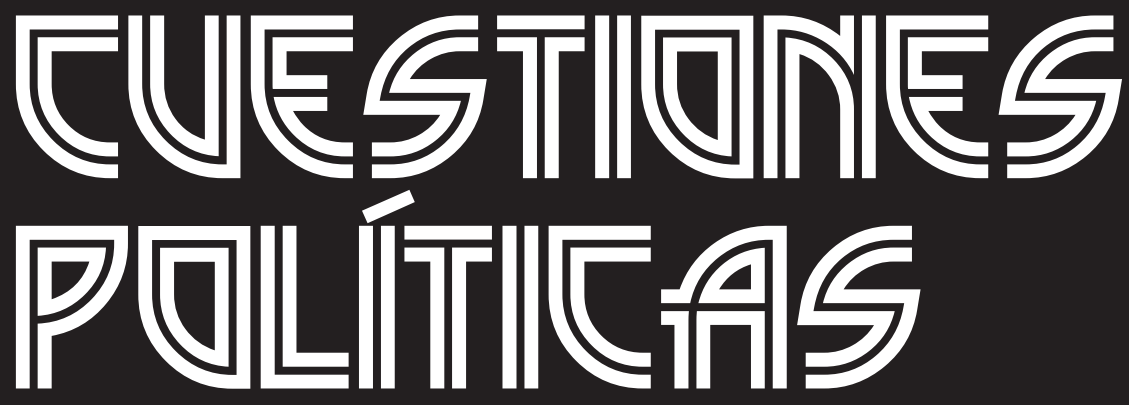

Instituto de Estudios Políticos y Derecho Público "Dr. Humberto J. La Roche' de la Facultad de Ciencias Jurídicas y Políticas de la Universidad del Zulia Maracaibo, Venezuela
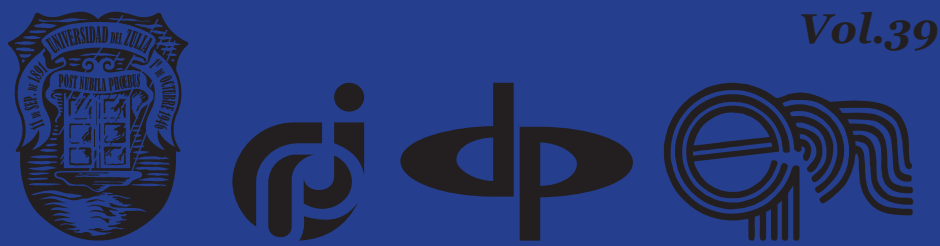


\title{
Regulatory framework for the fight against corruption in the National Police of Ukraine
}

\author{
DOI: https://doi.org/10.46398/cuestpol.3968.43
}

\author{
Vasylevych Vitalii ${ }^{*}$ * \\ Mozol Stanislav ${ }^{* *}$ \\ Poklonskyi Andrii ${ }^{* * *}$ \\ Poklonska Olena ${ }^{* * * *}$ \\ Zeleniak Polina ${ }^{5 * * * *}$
}

\section{Abstract}

The objective of the article is to analyze the main international regulations on overcoming corruption in the police, as well as the laws of Ukraine aimed at combating this phenomenon in the National Police. The theme of the study is the analysis of the legal framework for combating corruption in the police. The research methodology includes the following general and special legal methods: dialectical, logical, system-legal, normative-dogmatic, comparative-legal, and legal modeling method. The results of the investigation indicate the most effective means of combating corruption in the police of the most developed countries. By way of conclusion and with practical significance, Ukrainian anti-corruption legislation against police officers has been shown to be repressive, so it cannot be effective without measures to encourage law-abiding behaviour and the sense of anti-corruption of law enforcement officers. Emphasis is placed on the need to take measures to encourage the anti-corruption behaviour of police officers and to enshrine these provisions in relevant regulations.

* PhD (Law), Professor, Professor of the Department of Criminology and Penal Law of the National Academy of Internal Affairs, Ukraine. ORCID ID: https://orcid.org/oooo-0oo1-9351-4219. Email: vavian3@ukr.net

** Doctor of Law, Senior Researcher, Associate Professor of the Department of Criminology and Penal Law of the National Academy of Internal Affairs, Ukraine. ORCID ID: https://orcid.org/oooo-ooo22226-7908. Email: m_ctac@ukr.net

*** PhD (Law), Associate Professor, Professor of the Department of Private Law Disciplines of the Private Law University of Modern Knowledge. ORCID ID: https://orcid.org/oooo-0001-6721-655X. Email: subop@mail.ru

**** PhD (Law), Associate Professor, Professor of the Department of Public Law Disciplines of the Private Law University of Modern Knowledge. ORCID ID: https://orcid.org/oooo-0002-2079-1044. Email: Lenmok@mail.ru

***** PhD (Law), Lecturer of the Department of Criminology and Penal Law of the National Academy of Internal Affairs, Ukraine. ORCID ID: https://orcid.org/oooo-0003-0615-0803. Email: zelenyak2122@gmail.com 
Keywords: anti-corruption; corruption in the police; Ukraine's national police; international anti-corruption legislation; legal dissipations.

\section{Marco regulatorio para la lucha contra la corrupción en la Policía Nacional de Ucrania}

\section{Resumen}

El objetivo del artículo es analizar las principales regulaciones internacionales sobre la superación de la corrupción en la policía, así como las leyes de Ucrania destinadas a combatir este fenómeno en la Policía Nacional. El tema del estudio es el análisis del marco legal para combatir la corrupción en la policía. La metodología de investigación incluye los siguientes métodos legales generales y especiales: dialéctico, lógico, sistema-legal, normativo-dogmático, comparativo-legal y método de modelado legal. Los Resultados de la investigación indican cuales son los medios más efectivos para combatir la corrupción en la policía de los países más desarrollados. A modo de conclusión y con significado práctico, se ha demostrado que la legislación ucraniana de lucha contra la corrupción contra los agentes de policía es represiva, por lo que no puede ser eficaz sin medidas para fomentar el comportamiento respetuoso de la ley y el sentido de anticorrupción de los agentes del orden. Se hace hincapié en la necesidad de tomar medidas para fomentar el comportamiento anticorrupción de los agentes de policía y consagrar estas disposiciones en las regulaciones pertinentes.

Palabras clave: lucha contra la corrupción; corrupción en la policía; policía nacional de Ucrania; legislación internacional anticorrupción; disipaciones legales.

\section{Introduction}

The fight against corruption in Ukraine is one of the main tasks of law enforcement agencies (Shcherbakovskyi et al., 2020). The National Police of Ukraine is an executive body whose main tasks are the protection of human rights and freedoms, the fight against crime, the maintenance of public safety and order. To perform these and a number of other functions, police officers must act lawfully, transparently and impartially. Unfortunately, the population often faces manifestations of unscrupulous behavior of law enforcement officers, as evidenced by numerous appeals of citizens to the relevant authorities. 
The level of corruption in law enforcement agencies is growing every year. Thus, in 2020, 175 employees of the National Police were included in the Register of Corruption; 12 of them have been prosecuted for corruption offenses: 5 police officers - for accepting an offer, promise or receiving an illegal benefit, 7 police officers - for abusing influence, i.e. accepting an offer, promise or receiving an illegal benefit for themselves or another person for influencing a decision. 156 employees of the National Police were brought to administrative responsibility for late submission of property declarations (National Agency on Corruption Prevention, 2020).

International treaties play a particularly important role in preventing and countering corruption, given the global nature of the problem of corruption (Bondarenko et al., 2020). There are a number of international instruments, on which the relevant legislation of the Member States is built, to prevent and combat corruption in the police. That is why anticorruption measures in foreign countries are overwhelmingly similar. This is also explained by the processes of integration of legislation, active intergovernmental coordination of measures to combat offenses with signs of corruption, and the exchange of experience in conducting specific anticorruption measures.

To a greater extent, this applies to EU countries, although each country still has specific features given the peculiarities of their development, legal traditions, mentality and degree of activity of citizens (Grigorenko, 2014). Therefore, within this article we will consider the main international regulations on corruption prevention in the police agencies, which became the basis for the development of relevant legislation of Ukraine in this area, as well as regulations of our State aimed at corruption prevention in the National Police of Ukraine.

\section{Methodology}

The methodology of the Article is based on general and special methods of scientific knowledge, the use of which is determined by the purpose, object, and subject of research. Axiological method was applied to substantiate the importance of international and domestic regulations in the prevention of corruption offenses committed by the police. The method of hermeneutics was used in the process of studying international and domestic legal acts regulating the issue under consideration with their further interpretation. The method of analysis and synthesis helped to clarify the content of legal mechanism for preventing corruption offenses committed by police officers. The method of induction and deduction allowed to specify areas for improving legal measures for preventing corruption offenses committed by police. Legal and comparative method was used in order to compare the measures to prevent corruption offenses committed by police officers in 
Ukraine and in some other countries. The method of generalization helped to draw conclusions and suggestions.

\section{Literature Review}

The problems of corruption in the police have been studied by a large number of foreign and domestic scientists. For example, Moran (2002) examines anti-corruption strategies used by police in some areas of the United States and England. The author also studies the risks of corruption, compares different methods of combating this negative phenomenon and analyzes the role of specially authorized bodies to combat corruption.

Arrigo and Claussen (2003) believe that testing individuals before they are employed as police officers is an effective means of preventing corruption offenses, but it is currently used with a number of errors. Instead, researchers propose an authors' method of conducting a preemployment screening of law enforcement personnel, which should provide an appropriate level of assessment of trends in the behavior of future law enforcement officers and their propensity to corruption.

According to Punch (2000), corruption accompanies police activity constantly, and it is not a phenomenon that is so easy to eradicate. This requires a number of measures (management control, anti-corruption strategy, appropriate standards of conduct, effective methods of investigating such offenses), which must be harmoniously combined. To determine the most effective measures to combat this phenomenon, the author examines the experience of the 4 most progressive countries - USA, Great Britain, Belgium, and the Netherlands. The article uses the scientific works of such domestic scientists as Grigorenko (2014), Khan (2019), Kubaienko (2017), as well as a number of international and domestic regulations governing the relevant issues in this area.

\section{Results and Discussion}

In 1979, the Parliamentary Assembly of the Council of Europe adopted the Declaration on the Police (Parliamentary Assembly, 1979). It sets out the rules of civil service in the police, defines the procedure for execution of orders and the procedure for issuing orders from superiors to subordinates, as well as ethical provisions to be followed by police officers of different countries. These standards are aimed to ensure the integrity, incorruptibility and ethical conduct of law enforcement officers when performing their functions, to promote the development of measures necessary to prevent, detect, punish, and eradicate police corruption, and bring corrupt police officers to responsibility. According to the provisions of the Declaration, a police officer should act honestly, impartially, with a sense of personal 
dignity, refrain from corruption and resolutely oppose it; the police officer must carry out instructions duly given by his superior, but he (she) must refrain from following the instructions if he (she) is aware or should be aware that they are illegal; no criminal or administrative punishment may be applied to a police officer who refuses to carry out an illegal order; the police officer must bear personal responsibility for his (her) actions, as well as for illegal actions or omission committed on his instructions; a manager who will be responsible for the actions or omission of an employee should be appointed.

Given the urgency of ensuring the protection of the law enforcement system from corruption, the Global standards to combat corruption in police forces/services (Interpol, 2002) were adopted at the $71^{\text {st }}$ session of the General the Interpol Assembly in Cameroon. These standards are aimed at ensuring honesty, integrity and ethical conduct of police officers when performing their functions, assistance in developing the necessary measures to prevent, detect, punish, and eradicate corruption in the police of each Interpol member country, as well as to bring corrupt police officers to justice.

The concept of "corruption", given the above standards, covers all forms of abuse of power or official position, misuse of authority, bribery and other abuses (unlawful dissemination of confidential or restricted information, participation as organizer, performer, co-executor, instigator or accomplice in any of these acts, etc).

In order to prevent and combat corruption in the activities of police officers, the General Standards provide for the following measures (Article 4):

- use of disincentives to bribe individualswho perform or participate in the exercise of police functions or related functions.

- making every effort to ensure that mechanisms and systems for preventing, detecting, punishing, and eradicating corruption in the exercise of police functions or related functions in police forces/ services are in line with current practice recognized by the Interpol General Assembly.

- $\quad$ existence of an effective system that obliges police officers to report corruption and to protect those who report such facts in good faith.

- establishing mechanisms to encourage the participation of civil society in activities to prevent corruption in police forces/services.

- $\quad$ establishing and ensuring procedures for declaring and registering income, assets and commitments of police officers and the members of their families. 
The provisions of international legal acts are reflected in the relevant legislation of the signatory countries. Our State has implemented these norms in the Law of Ukraine "On Corruption Prevention" (LU 2014, October 14). At the same time, the special Law - the Law of Ukraine "On the National Police" (LU 580-VIII/2015, July 02) does not contain specific provisions on preventing or overcoming corruption in the police agencies. Therefore, when determining the range of anti-corruption measures in these agencies, one should first refer to the provisions of the general law "On Corruption Prevention", which state that the police officers are the subjects covered by this Law. A similar provision is contained in Part 1 of Article 61 of the Law of Ukraine "On the National Police", the provision of which states that "Police officers are subject to the restrictions set by the Law of Ukraine "On Corruption Prevention" and other laws of Ukraine".

Thus, the current legislation includes the measures to prevent corruption in the police:

1. Restrictions on the use of official powers or the position (Article 22 of the Law). A police officer is prohibited from using his or her official authority or position and related powers to gain an improper benefit for himself (herself) or others, including the use of any State or municipal property or funds in the private interest.

2. Restrictions on receiving gifts (Article 23 of the Law). It is prohibited to demand, ask for, and receive gifts for themselves or their relatives from legal entities or individuals directly or through other persons.

3. Restrictions on combination police activity with other activities (Article 25 of the Law of Ukraine "On Corruption Prevention" and Article 66 of the Law of Ukraine "On the National Police"). Police officers are prohibited from engaging in any other paid (other than teaching, research and creative activities, medical practice, instructional and judicial practice in sports) or entrepreneurial activities, be the members of the board, other executive or supervisory bodies, the supervisory board of the enterprise or organization with the purpose to receive the profit (except for cases when persons exercise management of shares owned by the State or territorial community, and represent the interests of the State or territorial community in the council (supervisory board), the audit commission of the business organization).

4. Restrictions on joint work of close persons (Article 27 of the Law). Police officers may not have direct control over persons close to them or be directly subordinate to them in connection with the performance of duties by persons close to them. When hiring, a police officer is obliged to inform the management of the body in which he (she) is applying for the position of persons close to them, who are working in this body. 
5. Restrictions after the cessation of activities related to the performance of functions of the State and local self-government (Article 26 of the Law). Police officers who have resigned or otherwise terminated activities related to the performance of State functions are prohibited from: - concluding employment agreements (contracts) or entering into transactions in the area of entrepreneurial activity with legal entities of private law or natural persons-entrepreneurs within a year from the date of termination of the relevant activity, if police officers exercised control powers, supervising or preparing or making appropriate decisions regarding the activities of these legal entities or natural persons-entrepreneurs;

6. disclosing or otherwise using in their interest's information that has become known to them in connection with the performance of official duties, except as provided by law; - representing the interests of any person in cases (including those before the courts) in which the other party is the body, enterprise, institution, organization in which (which) they worked on the moment of termination of the specified activity within a year from the date of termination of the relevant activity. 6) Prevention and settlement of conflicts of interest (Article 28 of the Law). Police officers are obliged to take measures to prevent the occurrence of real, potential conflict of interest, to notify the immediate superior about actual or potential conflict of interest no later than the next working day from the moment when the person learned or should have learned about the conflict of interest, to take measures to resolve real or potential conflict of interest. Police officers may not directly or indirectly encourage subordinates to make decisions in any way, commit acts or omissions contrary to the law in favor of their private interests or the private interests of third parties.

7. Financial control (Section VII of the Law), which provides for the following actions: submission by police of declarations of persons authorized to perform the functions of the State or local selfgovernment; accounting and publication of such declarations; their control and inspection by the National Agency of Corruption Prevention; establishing the terms for submission of declarations; monitoring the way of life of the declaring subjects (in order to establish the conformity of their standard of living to the property available to them and their family members and the income received by them in accordance with the declaration of the person authorized to perform the functions of State or local self-government); additional measures of financial control (the obligation of police officers to notify the National Agency of Corruption Prevention on the opening of foreign currency account in a non-resident bank by them or the members of their families, the receipt of income, acquisition of 
property or expenditure in excess of 50 subsistence minimums for employable persons as of January 01 of the respective year by by them or the members of their families, features of financial control measures in relation to certain categories of persons.

8. Prohibition on the receipt of benefits, services, and property by the National Police.

9. Special inspection (Article 56 of the Law of Ukraine "On Corruption Prevention" and Part 3 of Article 50 of the Law of Ukraine "On the National Police"). Information on the person applying for the position of a police officer is subject to special verification, in particular on: the existence of a court decision that has entered into force, according to which the person is prosecuted (including for corruption offenses), as well as the presence of a criminal record, its removal or expunging; the fact that the person has been previously subjected to administrative penalties for corruption-related offenses; the accuracy of the information specified in the declaration of the person authorized to perform the functions of the State or local self-government; the fact that a person is holding corporate rights; medical condition (in terms of a person's registration in psychoneurological or narcological health care institutions); education, availability of a scientific degree, academic title; a person's attitude to military service; the access to the State secret, if such admission is required in accordance with the qualification requirements for a particular position; prohibition of a person from holding relevant position provided by the provisions of the Law of Ukraine "On the clearance of the authorities".

10. Restrictions on service in the police. The Law of Ukraine "On the National Police" (Article 61) stipulates that a person who has been subjected to administrative or criminal liability for committing an offense related to corruption cannot be a police officer.

Disciplinary measures under Ukrainian law are also deterrent measures for police officers from committing corruption offenses. Thus, according to paragraph 9, Part 1, Art. 77 of the Law of Ukraine "On the National Police" a police officer is dismissed from service in the police, and the service in the police is terminated due to direct subordination to a close person. According to paragraph 10 of the same article, a police officer is dismissed from the police service in case of entry into force of a court decision to prosecute a police officer for an administrative offense related to corruption or a criminal offense (including corruption).

Additionally, according to Part 5, Art. 17 of the Law of Ukraine "On the disciplinary Statute of the National Police” (LU 2337-VIII/2018, March 15) during the trial of the case of corruption, administrative or criminal offense of a police officer, the latter may be suspended from office. 
In addition, administrative or even criminal measures may be taken regarding the police, guilty of committing corruption offenses. Indeed, according to the provisions of the Code of Ukraine on Administrative Offenses (LU 1984, December 07), law enforcement officers are prosecuted for the following administrative corruption offenses: violation of restrictions on holding a job or combining it with other activities (Article 172-4); violation of statutory restrictions on the receipt of gifts (Article 1725); violation of financial control requirements (Article 172-6); violation of the requirements for the prevention and settlement of conflicts of interest (Article 172-7); illegal use of information that has become known to a person in connection with the performance of official duties (Article 172-8); failure to take measures to combat corruption (Article 172-9).

Criminal sanctions for police officers guilty of committing criminal corruption offenses are enshrined in the Criminal Code of Ukraine (LU 2001, April 05).

Such offenses are: misappropriation, embezzlement or conversion or property by malversation (Article 191); use of budget funds by an official contrary to their target allocation or in amounts exceeding approved expenditure limits, and also failure to comply with requirements related to proportional decrease of budget expenses or proportional financing of expenditure items of budgets of all levels pursuant to applicable budget legislation, where large amounts of budget funds are involved (Article 210); stealing, appropriation or extortion of firearms, ammunition, explosives or radioactive material, or obtaining them by fraud of abuse of office (Article 262); stealing, appropriation, extortion of narcotics, psychotropic substances or their analogues, or acquisition of same by fraud or abuse of office (Article 308); stealing, appropriation, extortion of precursors, or acquisition of precursors by fraud or abuse of office (Article 312).

Stealing, appropriation, extortion of equipment devised for making of narcotic or psychotropic substances, or their analogues, or acquisition of such equipment by fraud or abuse of office, and other unlawful actions involving such equipment (Article 313); violation of rules related to circulation of narcotics, psychotropic substances, their analogues or precursors (Article 320); bribery of an employee of an enterprise, institution or organization (Article 354); stealing, appropriation, or extortion of documents, stamps and seals, or acquiring them by fraud or abuse of office, or endamagement thereof (Article 364); abuse of power by an official of a legal entity of private law, regardless of the organizational and legal form (Article 364-1); abuse of power by persons providing public services (Article 365-2); acceptance of an offer, promise or receipt of an illegal benefit by an official (Article 368); illicit enrichment (Articles 368-2); bribery of an official of a legal entity of private law, regardless of the organizational and legal form (Article 3683 ); bribery of a person providing public services (Articles 368-4); offer, 
promise or provision of illegal benefit to an official (Article 369); abuse of influence (Articles 369-2); stealing, appropriation, extortion or fraudulent obtaining of weapons, ammunitions, explosive or other warfare substances, vehicles, military or special enginery, or other munitions, or abuse of office, by a military serviceman (Article 410).

Taking into account the above stated, one can see that Ukrainian anticorruption legislation against police officers is of repressive nature, as most corruption offenses are criminally liable.

The repressive mechanism cannot give an effective result without the introduction of measures to encourage obedient, anti-corruption behavior of police officers. Such measures are preventive in nature and aimed at leveling the desire of employees to violate anti-corruption legislation (Khan, 2019).

And we completely agree with this opinion. For example, the US police have set a high pension for employees who have a perfect track record. It all starts with careful selection, because it depends not only on the professionalism and competence of police officers, but also their resistance to moral temptations. Particular attention is paid to maintaining a high level of prestige of the police profession in society: each candidate has education, knowledge of a foreign language, impeccable biography not only of the candidate but also of his (her) family members, high degree of stress resistance, moral and volitional qualities, etc. (Grigorenko, 2014: 167).

Besides, the level of corruption in the police is significantly affected by the low level of material support of law enforcement. We consider this a serious mistake of the State, as the lack of financial motivation does not encourage police to cherish the service and refuse bribes. At the same time, it is important not only to increase salaries, but also to provide them with personal and medical insurance, to grant preferential conditions for the purchase of personal housing, access to free higher education, and so on.

Thus, the salaries of US police officers were significantly increased in the 1980 s, as well as there was an introduction of additional social benefits. And if American policemen used to be from the lower middle class, now they belong to the upper middle class.

Anti-corruption education, to which our country pays little attention, also takes an important place in prevention of corruption offenses. At the same time, this measure is actively used and proves its effectiveness in many countries around the world.

For example, in the Financial Police of Italy, anti-corruption prevention issues are studied in special courses. Anti-corruption workshops are common in the law enforcement agencies of the United Kingdom, Denmark, Moldova, and Poland, during which special attention is paid to preparing 
police officers for actions in case of provoking bribes or forcing them to commit other illegal acts (Grigorenko, 2014).

The maingoal of anti-corruption education is, firstly, to train professionals who will have the necessary professional skills and will be able to participate in the work of anti-corruption bodies; secondly, anti-corruption education will help to increase the level of legal culture and culture of public relations, devoid of elements of corruption, contribute to the conscious rejection of the phenomenon of corruption and its manifestations; thirdly, anti-corruption education is a component of anti-corruption propaganda and educates a person in the spirit of non-acceptance of corruption; fourthly, it facilitates access to reliable information on the phenomenon of corruption. Anticorruption education is provided in educational institutions in the form of teaching special courses on anti-corruption issues. Such activities can be carried out both by training police cadets and by working with current police officers within relevant trainings, seminars, etc. (Khan, 2019).

Much attention is also paid to the selection of candidates for the position of police officer. For example, in Canada, a police screening of a job applicant begins with the collection of information about a person after reaching the age of 12 (the State considers that it is the period of a person's personality formation), his (her) contacts at the place of previous and current residence, work or service (Kubaienko, 2017).

In the United States, police departments pay special attention to the issue of their staffing. High moral standards and fairly strict rules of conduct and discipline have been set for job candidates, as well as for police officers at all levels. Strict selection of candidates for the service has been introduced, which provides for a lie detector test. The Federal Bureau of Investigation, whose main task is to fight corruption, is constantly moving staff from one place to another to reduce the possibility of merging with local authorities and organized crime. Besides, there is a special department of internal investigations in the FBI's Main Directorate, which checks information about abuses of its employees (Grigorenko, 2014).

Besides, the United States monitors the well-being of police officers and their families by verifying declarations, monitoring credit card balances, valuing property owned by them, etc.

\section{Conclusions}

Thus, the National Police of Ukraine is a central executive body that implements State policy in the area of protection of human rights and freedoms, the interests of society and the State, combating crime, maintaining public safety and order. 
Despite the fact that the National Police is one of the specially authorized entities in the area of anti-corruption, the cases of corruption offenses in the police are not isolated, as evidenced by numerous complaints from citizens and relevant statistics.

To overcome this problem, Ukraine has implemented the provisions of international regulations on the prevention and fight against corruption in the police in its own legislation. Although the special Law "On the National Police" does not enshrine the relevant provisions, it refers to the Law "On Corruption Prevention", which directly prescribes measures to prevent corruption in the police.

The Criminal Code of Ukraine and the Code of Ukraine on Administrative Offenses enshrine corruption offenses for which criminal or administrative liability arises, as well as provide for appropriate sanctions. The Disciplinary Statute of the National Police provides for disciplinary liability for law enforcement officers guilty of committing corruption offenses.

Ukrainian anti-corruption legislation against police officers is of repressive nature, that's why it cannot work effectively without measures to encourage law-abiding, anti-corruption behavior of police officers.

This issue is addressed somewhat differently in progressive States: preference is given to anti-corruption education, careful selection of candidates, monitoring of their lifestyle, determining their susceptibility to corrupt behavior, creating a system of incentives for impeccable record, ensuring an adequate standard of living for police officers and their families.

Therefore, despite the fact that Ukrainian legislation in this area generally meets European standards, we, based on international experience, still need to move away from the repressive mechanism and implement measures to encourage anti-corruption behavior aimed at leveling the desire of police officers to violate anti-corruption legislation, and enshrine these latter in relevant regulations.

\section{Bibliographic References}

ARRIGO, Bruce A; CLAUSSEN, Natalie. 2003. "Police corruption and psychological testing: a strategy for preemployment screening" In: International journal of offender therapy and comparative criminology. Vol. 47, No. 3, pp. 272-290.

BONDARENKO, Olha; REZNIK, Oleg; GARMASH, Yevgen; ANDRIICHENKO, Nadiia; STOHOVA, Olha. 2020. "Participation of Ukrainein International Cooperation Against Corruption" In: Amazonia Investiga. Vol. 9, No. 29, pp. 407-416. Available online. In: https://doi.org/10.34069/ $\mathrm{AI} / 2020.29 .05 \cdot 45$. Date of consultation: 21/12/2020. 
Vasylevych Vitalii, Mozol Stanislav, Poklonskyi Andrii, Poklonska Olena y Zeleniak Polina

694

Regulatory framework for the fight against corruption in the National Police of Ukraine

GRIGORENKO, Irina. 2014. "Foreign experience counteraction inside abuse and corruption in the police" In: Legal journal of the National Academy of Internal Affairs. No. 1, pp. 164-175.

INTERPOL. 2002. Global standards to combat corruption in police forces/ services. Available online. In: https://policehumanrightsresources.org/ content/uploads/2001/o1/Global-Standards-to-Combat-Corruptionin-Police-Forces-Services.pdf?x96812. Date of consultation: 21/12/2020.

KHAN, Oleksandr. 2019. "Measures to prevent and combat corruption in police agencies" In: Foundation of Local Democracy. Available online. In: http://fmd.kh.ua/news/zahodi-zapobigannya-ta-protidiyi-koruptsiyi-vorganah-politsiyi.html. Date of consultation: 21/12/2020.

KUBAIENKO, Andrii. 2017. "Problems preventing and combating corruption in the police: international experience" In: Actual problems of domestic jurisprudence. No. 3, pp. 114-118.

MORAN, Jon. 2002. "Anti-Corruption Reforms in the Police: Current Strategies and Issues" In: The Police Journal. Vol. 75, No. 2, pp. 137-159.

NATIONAL AGENCY ON CORRUPTION PREVENTION. 2020. “2018 people have been included in the Register of Corrupt Individuals since the beginning of 2020" In: NACP Official Website. Available online. In: https://nazk.gov.ua/uk/novyny/2018-osib-potrapylo-do-reyestrukoruptsioneriv-z-pochatku-2020-roku-nazk/. Date of consultation: $21 / 12 / 2020$.

PARLIAMENTARY ASSEMBLY (COUNCIL OF EUROPE). 1979. Declaration on the Police, adopted by the Resolution 690. Available online. In: http://assembly.coe.int/nw/xml/XRef/Xref-XML2HTML-en. asp?fileid=16101. Date of consultation: 21/12/2020.

PUNCH, Maurice. 2000. "Police Corruption and its Prevention" In: European Journal on Criminal Policy and Research. No. 8, pp. 301-324. Available online. In: doi:10.1023/A:1008777013115. Date of consultation: $21 / 12 / 2020$.

SHCHERBAKOVSKYI, Mikhailo; STEPANIUK, Ruslan; KIKINCHUK, Vasyl; ODERIY, Oleksiy; SVYRYDOVA, Liudmyla. 2020. "Evidentiary Problems in the Investigation of Corruption Crimes in Ukraine". In: Amazonia Investiga, Vol. 9, No. 32, pp. 117-124. Available online. In: https://doi. org/10.34069/AI/2020.32.08.12. Date of consultation: 21/12/2020.

LAW OF UKRAINE. 1984. Law 80731-X/1984, December 07. Code of Ukraine on Administrative Offenses. The Verkhovna Rada of Ukraine. Available online. In: https://zakon.rada.gov.ua/laws/show/80731-10\#Text. Date of consultation: 21/12/2020. 
LAW OF UKRAINE. 2001. Law 2341-III/2001, April 05. Criminal Code of Ukraine. The Verkhovna Rada of Ukraine. Available online. In: http://zakon.rada.gov.ua/laws/show/2341-14. Date of consultation: 21/12/2020.

LAW OF UKRAINE. 2014. Law 1700-VII/2014, October 14. On Corruption Prevention. TheVerkhovna Rada of Ukraine. Available online. In: https:// zakon.rada.gov.ua/laws/show/1700-18\#Text. Date of consultation: 21/12/2020.

LAW OF UKRAINE. 2015. Law 580-VIII/2015, July 02. On the National Police. The Verkhovna Rada of Ukraine. Available online. In: https://zakon. rada.gov.ua/laws/show/580-19\#Text. Date of consultation:21/12/2020.

LAW OF UKRAINE. 2018. Law 2337-VIII/2018, March 15. On the Disciplinary Statute of the National Police. The Verkhovna Rada of Ukraine. Available online. In: https://zakon.rada.gov.ua/laws/show/2337-19\#Text. Date of consultation: 21/12/2020. 

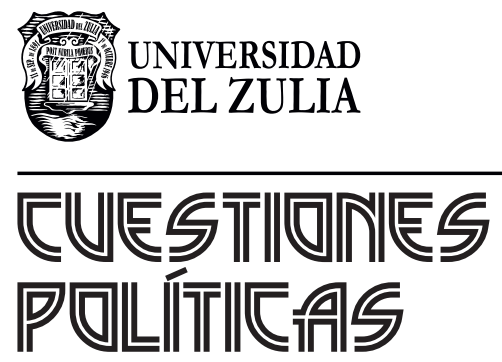

Vol.39 No 68

Esta revista fue editada en formato digital y publicada en enero de 2021, por el Fondo Editorial Serbiluz, Universidad del Zulia. Maracaibo-Venezuela 